\title{
Food sources, energy and nutrient intakes of adults: 2013 Philippines National Nutrition Survey
}

\author{
Imelda Angeles-Agdeppa ${ }^{1 *} \mathbb{D}$, Ye Sun², Liya Denney ${ }^{3}$, Keith V. Tanda ${ }^{1}$, Royce Ann D. Octavio ${ }^{1}$, Alicia Carriquiry ${ }^{4}$ and
} Mario V. Capanzana'

\begin{abstract}
Background: Comprehensive assessment of dietary intakes of foods and nutrients in Filipino adults are lacking. This study evaluated energy and nutrient intakes and food sources of key nutrients consumed by Filipino adults.

Methods: The participants were from the 2013 National Nutrition Survey wherein food intake of young adults aged 19-49 years $(n=12,896)$ and older adults aged 50 years and above $(n=7853)$ were collected using 24-h recalls.

Usual nutrient intakes were estimated using PC-SIDE program. The Philippines Dietary Reference Intakes were used to calculate proportions of inadequate intake using Estimated Average Requirement (EAR) and Acceptable Macronutrient Distribution Ranges (AMDR). Energy adequacy was evaluated using the Institute of Medicine (IOM) equation for Estimated Energy Requirements (EER).

Results: The nutrient intakes with the highest prevalence of inadequacy (>50\%) were: iron (97-99\%), vitamin C (96-98\%), calcium (95-98\%), riboflavin (86-91\%), folate (89-90\%), thiamine (73-89\%), energy (67-70\%), total fat (55-67\%), and vitamin A (54-56\%). Refined rice, pork and breads contributed most to daily intakes of energy, protein, carbohydrates, thiamine, riboflavin, and iron. Low intake of vegetables, fruits and dairy was common in both age groups.

Conclusions: This study demonstrated that intakes of many nutrients were markedly inadequate among adults in the Philippines, due to the rice-dominant dietary pattern with few nutrient-dense foods. These results can be used to support the development of specific interventions to improve the shortfalls in nutrient intakes.
\end{abstract}

Keywords: Usual nutrient intake, Food sources, Adults, Older adults, The Philippines

\section{Background}

Suboptimal diet is associated with a range of non-communicable diseases $(\mathrm{NCD})$, and it is potentially a major contributor to NCD mortality worldwide [1]. In the Philippines, dietary risk is the top risk factor for diseases and is estimated to account for $10.6 \%$ of total disability-adjusted life-years [2]. At present, the Philippines hosts the world's 12th largest population of about 100 million people, among which $7.3 \%$ are aged above 60 years. This percentage is expected to double by 2050 with a predicted increase

\footnotetext{
* Correspondence: iangelesagdeppa@yahoo.com.ph

1 Department of Science and Technology, Food and Nutrition Research Institute, Bicutan, Taguig, Philippines

Full list of author information is available at the end of the article
}

in life expectancy and decrease in fertility rate [3]. However, despite being one of the fastest growing economies in Asia, one out of 10 adults suffers from chronic energy deficiency, and a high proportion (70-80\%) of adults is not meeting dietary requirements for many key micronutrients [4-6]. In addition, the prevalence of anemia among older adults is $24 \%$ [7]. On the other hand, similar to what happened in many other developing countries in Asia, Africa, and Latin America $[8,9]$, the Philippines is also experiencing double burden of malnutrition. Three out of 10 adults are overweight or obese [4], and the number of mortality and disability caused by ischemic heart disease, stroke, diabetes and chronic kidney disease has increased by more than $25 \%$ in the past decade [10].

(c) The Author(s). 2019 Open Access This article is distributed under the terms of the Creative Commons Attribution 4.0 International License (http://creativecommons.org/licenses/by/4.0/), which permits unrestricted use, distribution, and 
The aforementioned nutritional issues increase one's susceptibility particularly among the elderly to various diseases such as fractures, muscle loss, poorer immunity against infections, and other NCDs [11, 12]. Nutritionbased intervention strategies are one of the key solutions to improve the health status and quality of life of adult population in the Philippines.

In addition, dietary choices could differ within a population under multiple influences, such as age, gender and social economic status (SES). For instance, younger adults might embrace the nutrition transition towards a more "westernized" diet more than the older adults; and gender has an important impact on the social and biological determinants of health consequences, hence different nutritional needs [13]. Identifying such needs and differences is crucial to construct nutritional guidelines and solutions that are tailored to different population groups.

The Food and Nutrition Research Institute (FNRI) in the Philippines conducts National Nutrition Surveys (NNS) every 5 years, which are nationally representative and capture the food and beverage consumption of the Filipino population. However, the existing food composition table (FCT) developed in 1997 only included 12 nutrients, thus limiting the nutrient intakes data being reported. In addition, studies on nutrient intakes of Filipino adults by other researchers are limited both in terms of nutrients coverage and population representativeness. In an attempt to comprehensively characterize the diet of Filipino adults, this study expanded the existing FCT from 12 to 27 nutrients, with which we evaluated the usual intakes of energy and nutrients of adults using data from the 2013 NNS. In addition, the influences of age, gender and SES on nutrient intakes and food sources of key nutrients among adults were also investigated in this study.

\section{Methods}

\section{Study design and population}

This study used the data from the 2013 NNS. This is a cross-sectional, population-based survey that characterizes the health and nutritional status, foods consumption and dietary patterns of the Filipino population. The survey used a multi-staged stratified sampling design to represent all 80 provinces of the country covering both urban and rural areas. A total of 8592 sample households were selected from the NNS for the dietary survey with a response rate of $87.7 \%$. Briefly, 20,749 adults were used in this study, comprising specifically 12,896 aged 19-49 years old representing young adults and 7853 aged 50 years and over representing older adults. The age groups are aligned with the Philippine Dietary Reference Intake age grouping (PDRI, 2015). The Ethics Committee of FNRI approved the survey protocol. All surveyed households provided written informed consent prior to participation.

\section{Data collection \\ Demographic and socio-economic data}

Demographic and socio-economic information were collected from the 2013 NNS survey participants, including age, gender, and area of residence, marital status, education, and the body mass index (BMI). Wealth status of participants was defined by proxy indicators including household possession of vehicles, appliances, materials used for housing construction and sanitation facilities. Scores obtained from principal component analysis were used to define wealth quintiles as poorest, poor, middle, rich and richest. Chronic energy deficiency, overweight and obesity were determined using World Health Organization (WHO) definition [14].

\section{Dietary data}

Twenty four hours dietary recalls were conducted by registered nutritionist-dietitians through face-to-face interviews in households using structured questionnaires. The interviewer recorded all foods and beverages consumed on the previous day from the moment when they woke up until they went to sleep in the evening. The amount of foods and beverages consumed was estimated using household measures (cups, tablespoons and pieces) or through weighting of food samples. The weights of foods were converted to as purchased values using a portion to weight list for common foods compiled by FNRI. If the food was a dish, the interviewee was asked to describe the ingredients of the recipe or name the dish or recipe. The nutrient content of these composite foods were determined by breaking down the different ingredients in the recipe and each was calculated based on INFOODS Guidelines.

A first $24 \mathrm{~h}$ recall was collected in all members of all sampled households; and to estimate the day-to-day within-person variability in energy and nutrient intake, a second $24 \mathrm{~h}$ recall was carried out among members in $50 \%$ of randomly selected households. The repeated $24 \mathrm{~h}$ recalls were obtained on non-consecutive days to avoid correlation in nutrient intakes on consecutive days [15]. The values for the two $24 \mathrm{~h}$ recalls were averaged for each person to derive their usual intakes. For the remaining $50 \%$ of the respondents with only one $24 \mathrm{~h}$ recall, their 1 day recall data were unbiased estimate of their usual intake assuming the measurement error is additive [16].

\section{Data processing}

The estimation of energy and nutrients contents of foods consumed was done through the FNRI-Individual Dietary 
Evaluation System (IDES) which contains the expanded FCT developed from this project. The FCT was expanded from the original 12 nutrients to 27 nutrients, and it is the first time that these 27 nutrients were analyzed in a nationally representative Filipino population. Details about the development of the expanded FCT will be reported in another paper.

Implausible values of energy and nutrient intakes were identified by a process described below. For the evaluation of energy intake, Estimated Energy Requirement (EER) was calculated for each individual using the Institute of Medicine (IOM) equation [17] considering age, sex, body weight, height, and physical activity level (PAL) using the WHO STEP instrument [18]. The ratio of self-reported daily energy intake to the EER was then calculated for each person and each day of reporting. The calculated ratios were then transformed to the logarithmic scale and outliers below and above 3 SDs away from the mean were excluded [19]. Five hundred fifteen subjects were excluded from this exercise. For micronutrients, excessive intakes were defined as those that exceeded 1.5 times of the 99th percentile of the observed intake distribution in the respective age group. Intakes above this upper limit were substituted by a random value generated from a uniform distribution in the interval with lower bound equal to the 95th percentile of observed intake and an upper bound equal to 1.5 times of the 99th percentile [19].

To investigate the food sources of energy and nutrients, a list of 87 food groups under 9 major categories (Table 1) was created in a similar format to the food categories published by United Nations Food and Agriculture Organization (FAO) [20] and United States Department of Agriculture (USDA) [21], while reflecting Filipinos' frequently consumed foods and traditional way of consumption. All foods, including those less consumed foods, were considered in the analysis.

\section{Statistical analysis}

Mean and usual intake distributions of energy and nutrients were estimated using the PC-SIDE software (Software for Intake Distribution Estimation version 1.0, Iowa State University, IA, USA) [22]. This method developed by Iowa State University could account for the within-person variability of daily intakes across different days, and therefore only reflecting the betweenperson variability [16]. To determine if the mean differences of usual nutrient intakes across different age and gender subgroups were statistically significant, Analysis of Covariance (ANCOVA) was used with adjustment for total energy intake.

PDRI was used to evaluate nutrient inadequacies [23]. Where applicable, the prevalence of inadequacy in a group is estimated as the proportion of individuals with usual intakes below the Estimated Average Requirement (EAR), using the EAR cut-point method [24]. Due to a skewed distribution of iron intake, a probability approach was used instead to assess the prevalence of inadequate iron intake: the risk of inadequacy of each individual was computed first, and the prevalence of inadequate intake was estimated as the average risk of inadequacy [25]. Intakes of carbohydrates, fat, and protein were evaluated as percentage of total energy intake, and inadequacy or excessive intake was classified as less than the lower limit or higher than the upper limit of the Acceptable Macronutrient Distribution Ranges (AMDR). Additional file 1: Table S1 summarizes the EAR and AMDR benchmarks used in this study. Assessment of nutrient adequacy was also computed by gender, age groups, and wealth quintiles, and hypothesis testing comparing two population proportions was used to test the differences in prevalence of inadequacies across various subgroups.

Stata (Stata Statistical Software: Release 15. StataCorp, TX, USA) was used for data management, calculation of summary statistics, and statistical tests of differences. A $p$-value of $<0.05$ was considered significant in all statistical tests. Survey weights were applied in all datasets and calculations to represent national estimates through the complex survey design.

\section{Results}

Demographic and socio-economic characteristics, and nutritional status of the study population

Table 2 summarizes the demographic and socio-economic characteristics of the two age groups. Among the young adults and the older adults, respectively 53.8 and $45.1 \%$ were males. Approximately half of the study population resided in urban areas, and they were approximately equally distributed across the 5 wealth quintiles. Half of the older adults (51.0\%) only attained elementary education, while majority of the younger adults completed high school or higher education (74.8\%). The prevalence of chronic energy deficiency among young and older adults was 10.4 and $15.5 \%$ respectively, while 27.7 and $28.5 \%$ were overweight/obese.

\section{Energy and macronutrient intakes}

Table 3 summarizes the mean usual intakes of energy and nutrients by age and gender subgroups. The mean usual energy intake (mean \pm standard error) was $1828 \pm$ $6 \mathrm{kcal} /$ day (young adults) and $1527 \pm 6 \mathrm{kcal} /$ day (older adults), which was 30.2 and $33.5 \%$ lower than the mean estimated EER of $2620 \pm 4 \mathrm{kcal} /$ day and $2297 \pm 5 \mathrm{kcal} /$ day respectively.

Overall, younger adults consumed significantly more energy and most of the macronutrients than the older adults with the exception of carbohydrates. Males consumed 
Table 1 Food group classification

\begin{tabular}{|c|c|c|}
\hline Milk & Vegetables & Sweets \\
\hline Adult formula (fortified milk powder) & Dark green leafy vegetables & Sweet bakery products \\
\hline Cow's milk (fluid and powdered) & Spinach & Cookies \\
\hline Other milk & Broccoli & Biscuits \\
\hline Cheese & Cabbage, green & Sweet breads \\
\hline Yoghurt & Local leafy/petioles/salad vegetables & Cakes \\
\hline Meats/Fish/other protien sources & Deep yellow vegetables & Ice cream, popsicles \\
\hline Beef & Carrot & Candy \\
\hline Carabeef & Sweet potato, yellow & Sugar \\
\hline Pork & Cassava, yellow & Syrup \\
\hline Goat/lamb & Squash fruit & Preserves/jams/jellies \\
\hline Chicken & Squash, summer fruits & Native desserts/snacks \\
\hline Duck & Starchy vegetables & Sugar sweetened beverages \\
\hline Sausages/hotdogs & Sweet potato & Fruit-based beverages \\
\hline Luncheon meats/cold cuts & Potato & Concentrated fruit juice drinks \\
\hline Fish & Other vegetables & Powdered fruit flavored drinks \\
\hline Eggs & Vegetable products/processed vegetables & Soft drinks \\
\hline Beans/nuts & Fruit \& 100\% fruit juice & Chocolate/chocolate flavor beverages \\
\hline Grains \& Grain products & Apple & Other sweetened beverages \\
\hline Refined rice & Avocado & Mixed dishes \\
\hline Cereal & Banana & Meat-based mixed dishes \\
\hline Bread & Mango & Beans-based mixed dishes \\
\hline Crackers & Melon & Grain-based mixed dishes \\
\hline Pancakes, waffles, French toast & Citrus fruits & Soups \\
\hline Noodles & Cherries/berries & Other foods \& beverages \\
\hline Pasta & Papaya & Non-alcoholic beverages \\
\hline Corn grits & 100\% Fruit juice & Alcoholic beverages \\
\hline \multirow[t]{3}{*}{ Cornmeal } & fats/Oils & Savory snacks \\
\hline & Fats & Condiments, sauces, herbs, spices, other seasonings \\
\hline & Oils & \\
\hline
\end{tabular}

significantly higher energy and many nutrients than females within both age groups. It is also worth noting that the mean consumption of dietary fiber, ranged from 7.6-10.1 g, is far below the recommended nutrient intake of 20-25 g/ day for adults.

When examined as percentage of total energy, fat, protein, and carbohydrates contributed to $12.4-16.3 \%, 13.2-$ $13.5 \%$, and $70.3-73.2 \%$ of daily energy intake, respectively. Comparing against the AMDR recommendations, 55-67\% of the study population did not consume adequate fat (Table 4). The prevalence of inadequate fat intake was significantly higher in older adults, among males (Table 4), and in poor and poorest wealth quintiles (Table 5).

Protein intake was also evaluated with the EAR in g/day. Unlike when comparing with AMDR, a high prevalence of inadequacy was observed across all age and gender groups, with a more serious situation for older adults, females (Table 4), and in poor and poorest wealth quintiles (Table 5).

\section{Micronutrient intakes}

High prevalence of inadequate micronutrient intakes were found for iron (97-99\%), vitamin C (96-98\%), calcium (95-98\%), folate (89-90\%), riboflavin (86-91\%), thiamine (73-89\%), and vitamin A (54-66\%) (Table 4). For micronutrients with no established EAR recommendations, including vitamin $\mathrm{D}$, vitamin $\mathrm{E}$, magnesium and potassium, the mean intakes were also far from the adequate intakes.

On average, mean usual intakes of most vitamins and minerals were siginificantly higher in young adults than in older adults. A differing result was observed for vitamin $C$ as the average intake of older adults is higher than that of younger adults, though both were far below 
Table 2 Demographic, socio-economic characteristics and nutritional status of the study population

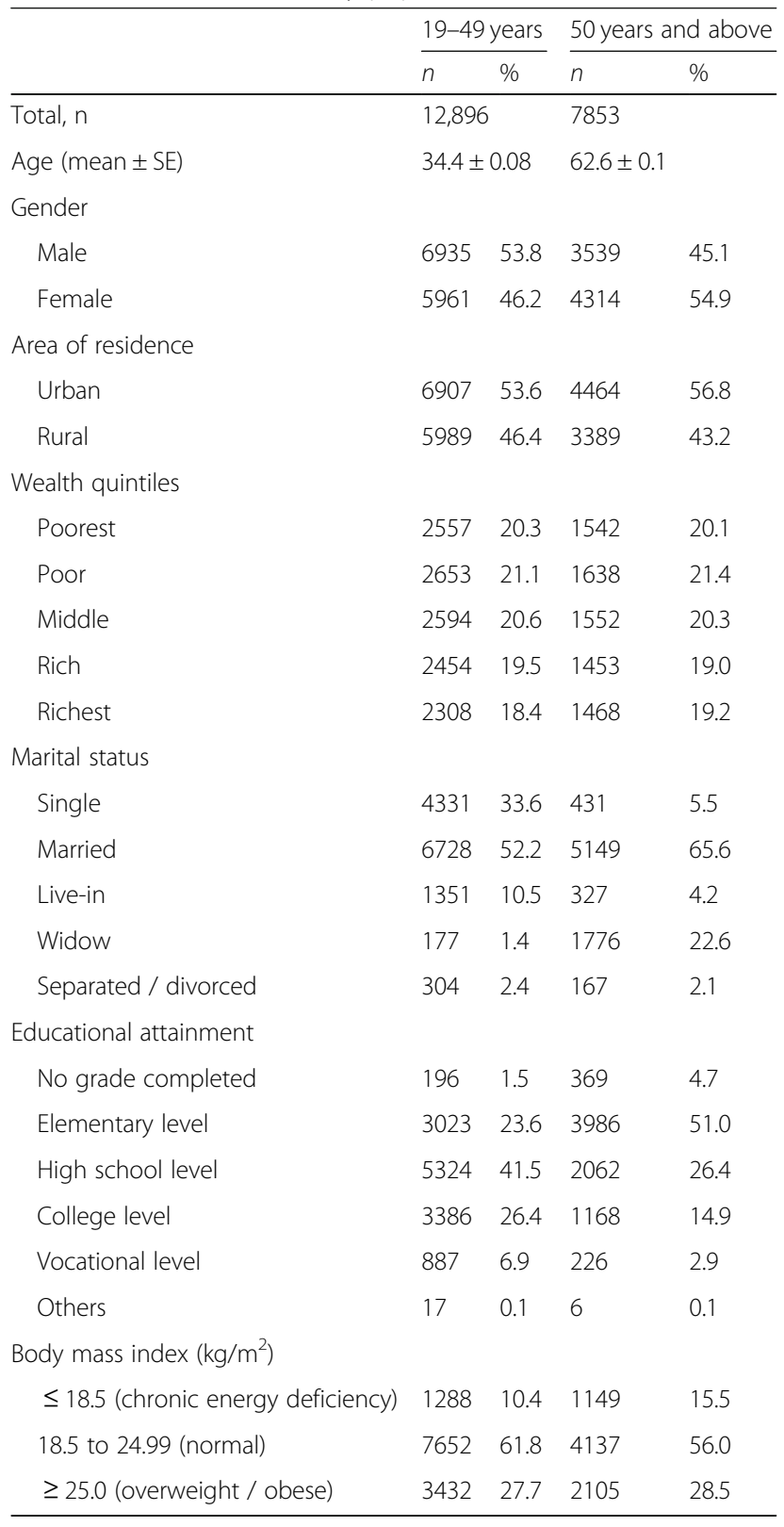

the EAsR of $52-60 \mathrm{mg} / \mathrm{d}$. In both age groups, the mean consumption of male adults for most vitamins and minerals was significantly higher than females (Table 3).

Corresponding to the differences observed in mean usual intakes, the prevalence of inadequacy increases significantly with age for many micronutrients, in particular thiamine, niacin, vitamin $\mathrm{A}$, vitamin $\mathrm{B} 6$, vitamin $\mathrm{B} 12$, phosphorus, and zinc. Also, females might be at higher risk of inadequacy for thiamine, niacin, vitamin A, vitamin B6, vitamin B12, folate, iron, calcium and phosphorus than males in both age groups, while males might be at higher risk for vitamin $\mathrm{C}$ and zinc inadequacy (Table 4).
Higher prevalence of inadequacy was observed among the poorest group for most micronutrients. It is worth noting that the prevalence of inadequacy in vitamin $\mathrm{C}$, folate, iron and calcium remained high across the wealth quintiles, and that more than $50 \%$ of adults did not consume adequate vitamin $\mathrm{C}$, folate, riboflavin, thiamine, vitamin A (only for older adults), iron and calcium even in the highest wealth index group (Table 5).

\section{Consumption rate and mean consumption per capita of major food groups}

Grains, meat and proteins, sweets and vegetables were the top 4 major food groups consumed in both age groups in terms of consumption rate as well as mean intake per capita (Table 6). Grains, mainly refined rice, played a dominant role in Filipino's diet (mean per capita 290.8-350.4 g/ day). Only less than $25 \%$ of adults consumed fruit, and even fewer consumed milk (9.3-13.4\%). The mean consumption per capita of vegetables (66.4-70.1 g/day), fruit (24.4-29.7 $\mathrm{g} /$ day) and milk (2.8-3.2 g/day) was far from the recommended 3 servings/day of vegetables, 2-3 servings/day of fruit, and 1 glass/day of milk [26], and this could explain partially the high prevalence of nutrient inadequacies.

\section{Food sources of energy and nutrients}

Figures 1 and 2 depict percentage contribution of the 9 major food groups to energy, macronutrients, and micronutrients with high prevalence of inadequacy (> $50 \%)$. The top 3 major food sources of energy were grains (68.8-69.7\%), meats and other protein-rich foods (13.3-15.5\%), and sweets (7.5-7.6\%).

Grains contributed nearly $70 \%$ of daily energy, more than $80 \%$ of carbohydrates, half of thiamine, folate, iron, and protein, and one third of calcium and riboflavin. Meat and other protein-rich foods were the source of half of fat, protein, vitamin $\mathrm{A}$, and riboflavin intakes, one third of thiamine, calcium, and iron intakes, and one fifth of folate intake. Vegetables contributed $40-50 \%$ of vitamin C, $40 \%$ of vitamin A, and less than $20 \%$ of folate, calcium, and $10 \%$ of riboflavin, thiamine, and iron. Approximately $20-30 \%$ of vitamin $C$ was from fruits and a similar percentage from sweet foods, mainly from fruit-based beverages and fortified sweetened beverages. Milk only contributed $0.4-0.7 \%$ of total energy intake due to the very low consumption rate in this population, but being a nutrient-dense food, milk still contributed $3.9-5.7 \%$ of calcium, $3-5.3 \%$ of riboflavin, and $1.9-3.2 \%$ of vitamin A. Fats and oils contributed less than $20 \%$ of total fat intake, and minimal amounts to other nutrients. Mixed dishes and other foods and beverages played a litthe role in the energy and nutrient intakes. The top major sources of energy and nutrients are also available (see Additional file 2: Table S2, Additional file 3: Table S3 and Additional file 4: Table S4. 
Table 3 Mean usual nutrient intakes of Filipino adults by age and gender groups: 8th NNS 2013

\begin{tabular}{|c|c|c|c|c|c|c|}
\hline \multirow[t]{3}{*}{ Nutrients } & \multicolumn{3}{|c|}{ 19-49 years (young adults) } & \multicolumn{3}{|c|}{50 years and above (older adults) } \\
\hline & \multirow{2}{*}{$\begin{array}{l}\text { Both } \\
\text { genders }\end{array}$} & \multicolumn{2}{|l|}{ Gender } & \multirow{2}{*}{$\begin{array}{l}\text { Both } \\
\text { genders }\end{array}$} & \multicolumn{2}{|l|}{ Gender } \\
\hline & & Male & Female & & Male & Female \\
\hline Sample, $n$ & 12,896 & 6935 & 5961 & 7853 & 3593 & 4314 \\
\hline \multicolumn{7}{|l|}{ Macronutrients } \\
\hline Energy (kcal/d) & $1828 \pm 6^{a}$ & $2096 \pm 8^{b}$ & $1535 \pm 6$ & $1527 \pm 6$ & $1767 \pm 7^{b}$ & $1322 \pm 6$ \\
\hline Total fat $(\mathrm{g} / \mathrm{d})$ & $32.2 \pm 0.2^{a}$ & $34.7 \pm 0.3^{b}$ & $29.5 \pm 0.2$ & $21.2 \pm 0.2$ & $23.2 \pm 0.4^{b}$ & $19.6 \pm 0.2$ \\
\hline Saturated fat (g/d) & $14.3 \pm 0.1^{\mathrm{a}}$ & $15.2 \pm 0.1$ Ns & $13.4 \pm 0.1$ & $10.3 \pm 0.1$ & $11.0 \pm 0.1^{\text {NS }}$ & $10.0 \pm 0.1$ \\
\hline MUFA (g/d) & $10.8 \pm 0.1^{\mathrm{a}}$ & $11.6 \pm 0.1^{b}$ & $10.1 \pm 0.1$ & $7.5 \pm 0.1$ & $8.0 \pm 0.1^{\text {NS }}$ & $7.0 \pm 0.1$ \\
\hline PUFA (g/d) & $5.3 \pm 0.1^{\mathrm{a}}$ & $5.9 \pm 0.1$ NS & $4.8 \pm 0.1$ & $3.7 \pm 0.1$ & $3.9 \pm 0.1^{\mathrm{b}}$ & $3.4 \pm 0.1$ \\
\hline Protein (g/d) & $60.1 \pm 0.2^{a}$ & $68.7 \pm 0.3^{\text {NS }}$ & $50.7 \pm 0.2$ & $50.1 \pm 0.2$ & $58.3 \pm 0.3^{b}$ & $43.0 \pm 0.2$ \\
\hline Carbohydrates (g/d) & $322 \pm 1^{\text {NS }}$ & $372 \pm 1^{b}$ & $266 \pm 1$ & $273 \pm 1$ & $317 \pm 2^{\text {NS }}$ & $237 \pm 1$ \\
\hline Total sugars (g/d) & $26.3 \pm 0.1^{\mathrm{a}}$ & $25.0 \pm 0.2^{\mathrm{Ns}}$ & $28.0 \pm 0.2$ & $25.7 \pm 0.2$ & $24.7 \pm 0.2^{\text {NS }}$ & $26.5 \pm 0.2$ \\
\hline Dietary fiber (g/d) & $9.1 \pm 0.03^{\mathrm{a}}$ & $10.1 \pm 0.1^{b}$ & $8.0 \pm 0.04$ & $8.5 \pm 0.04$ & $9.5 \pm 0.1^{b}$ & $7.6 \pm 0.1$ \\
\hline \multicolumn{7}{|c|}{ As percentage of total energy } \\
\hline Total fat (\%) & $15.1 \pm 0.1^{\mathrm{a}}$ & $14.0 \pm 0.5^{b}$ & $16.3 \pm 0.1$ & $13.2 \pm 0.1$ & $12.4 \pm 0.1$ Ns & $13.8 \pm 0.1$ \\
\hline Protein (\%) & $13.3 \pm 0.02^{\mathrm{a}}$ & $13.2 \pm 0.04^{b}$ & $13.4 \pm 0.02$ & $13.4 \pm 0.02$ & $13.5 \pm 0.04^{b}$ & $13.3 \pm 0.03$ \\
\hline Carbohydrates (\%) & $71.1 \pm 0.1^{\mathrm{a}}$ & $71.9 \pm 0.1^{b}$ & $70.3 \pm 0.1$ & $73.0 \pm 0.1$ & $73.2 \pm 0.1$ NS & $72.9 \pm 0.1$ \\
\hline \multicolumn{7}{|l|}{ Vitamins } \\
\hline Thiamine (mg/d) & $0.8 \pm 0.01^{a}$ & $0.9 \pm 0.01^{b}$ & $0.7 \pm 0.01$ & $0.6 \pm 0.03$ & $0.7 \pm 0.01^{b}$ & $0.6 \pm 0.03$ \\
\hline Riboflavin (mg/d) & $0.7 \pm 0.01^{\mathrm{a}}$ & $0.8 \pm 0.01$ Ns & $0.6 \pm 0.01$ & $0.6 \pm 0.04$ & $0.6 \pm 0.01^{b}$ & $0.5 \pm 0.03$ \\
\hline Niacin (mg NE/d) & $19.5 \pm 0.1^{\mathrm{a}}$ & $22.3 \pm 0.1^{\text {NS }}$ & $16.4 \pm 0.1$ & $16.6 \pm 0.1$ & $19.2 \pm 0.1^{b}$ & $14.2 \pm 0.1$ \\
\hline Vitamin B6 (mg/d) & $1.6 \pm 0.01^{\mathrm{a}}$ & $1.8 \pm 0.01^{\mathrm{b}}$ & $1.5 \pm 0.01$ & $1.4 \pm 0.01$ & $1.5 \pm 0.01^{b}$ & $1.2 \pm 0.01$ \\
\hline Vitamin B12 ( $\mu \mathrm{g} / \mathrm{d})$ & $4.0 \pm 0.01^{\mathrm{a}}$ & $4.4 \pm 0.02^{b}$ & $3.5 \pm 0.02$ & $3.6 \pm 0.02$ & $4.2 \pm 0.03^{b}$ & $3.1 \pm 0.02$ \\
\hline Vitamin A ( $\mu \mathrm{g}$ RE/d) & $470 \pm 2^{a}$ & $505 \pm 3^{b}$ & $433 \pm 3$ & $408 \pm 3$ & $447 \pm 4^{b}$ & $375 \pm 3$ \\
\hline Vitamin C (mg/d) & $23.4 \pm 0.1^{\mathrm{a}}$ & $22.7 \pm 0.2^{\mathrm{NS}}$ & $22.8 \pm 0.2$ & $24.1 \pm 0.2$ & $24.4 \pm 0.3^{\text {NS }}$ & $23.8 \pm 0.2$ \\
\hline Vitamin E (mg a-TE/d) & $2.9 \pm 0.01^{\mathrm{a}}$ & $3.2 \pm 0.02^{b}$ & $2.6 \pm 0.02$ & $2.5 \pm 0.02$ & $2.8 \pm 0.03^{b}$ & $2.3 \pm 0.02$ \\
\hline Vitamin D $(\mu \mathrm{g} / \mathrm{d})$ & $3.2 \pm 0.01^{\mathrm{a}}$ & $3.5 \pm 0.02^{b}$ & $2.9 \pm 0.02$ & $3.0 \pm 0.02$ & $3.4 \pm 0.03^{b}$ & $2.7 \pm 0.02$ \\
\hline Folate ( $\mu \mathrm{g}$ DFE/d) & $190 \pm 1^{\mathrm{a}}$ & $203 \pm 1^{b}$ & $177 \pm 1$ & $182 \pm 1$ & $196 \pm 2^{b}$ & $171 \pm 2$ \\
\hline \multicolumn{7}{|l|}{ Minerals } \\
\hline Calcium (mg/d) & $312 \pm 1^{a}$ & $340 \pm 1^{b}$ & $281 \pm 1$ & $308 \pm 2$ & $328 \pm 2^{b}$ & $268 \pm 2$ \\
\hline Iron $(\mathrm{mg} / \mathrm{d})$ & $8.8 \pm 0.03^{\mathrm{a}}$ & $9.6 \pm 0.04^{b}$ & $7.9 \pm 0.04$ & $7.5 \pm 0.04$ & $8.2 \pm 0.1^{b}$ & $6.7 \pm 0.04$ \\
\hline Phosphorus (mg/d) & $882 \pm 3^{a}$ & $1012 \pm 4^{\text {NS }}$ & $739 \pm 3$ & $750 \pm 3$ & $869 \pm 5^{\text {NS }}$ & $647 \pm 3$ \\
\hline Sodium (mg/d) & $821 \pm 3^{a}$ & $851 \pm 5^{b}$ & $817 \pm 5$ & $727 \pm 5$ & $699 \pm 6^{b}$ & $667 \pm 5$ \\
\hline Zinc (mg/d) & $6.8 \pm 0.1^{\mathrm{a}}$ & $7.5 \pm 0.1 \mathrm{NS}$ & $5.8 \pm 0.1$ & $5.5 \pm 0.1$ & $6.2 \pm 0.1^{\text {NS }}$ & $4.9 \pm 0.1$ \\
\hline Magnesium (mg/d) & $181 \pm 1^{a}$ & $204 \pm 1^{b}$ & $155 \pm 1$ & $159 \pm 1$ & $182 \pm 1^{\mathrm{b}}$ & $140 \pm 1$ \\
\hline Potassium (mg/d) & $1271 \pm 4^{\mathrm{a}}$ & $1392 \pm 5^{b}$ & $1140 \pm 5$ & $1155 \pm 5$ & $1282 \pm 8^{b}$ & $1046 \pm 6$ \\
\hline Selenium $(\mu \mathrm{g} / \mathrm{d})$ & $103.1 \pm 0.3^{\mathrm{a}}$ & $117.8 \pm 0.5^{\mathrm{b}}$ & $87.3 \pm 0.4$ & $84.5 \pm 0.4$ & $97.0 \pm 0.6^{b}$ & $73.6 \pm 0.4$ \\
\hline
\end{tabular}

Abbreviations: MUFA Monounsaturated fatty acids, PUFA Polyunsaturated fatty acids, NE Niacin equivalent, RE Retinol equivalent, $a$-TE a-tocopherol equivalent, DFE Dietary folate equivalent

Values shown are mean \pm standard error of usual nutrient intakes

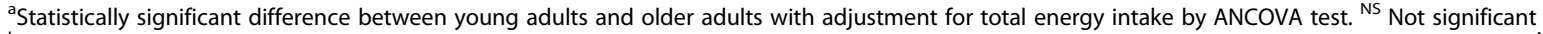
${ }^{b}$ Statistically significant difference between male and female adults of the same age group with adjustment for total energy intake by ANCOVA test. NS Not significant

\section{Discussion}

Our study investigated the usual intakes of energy and nutrients, and their primary food sources among young and older adults in the Philippines. To our knowledge, this is the first study to provide a comprehensive overview of the dietary intakes of 27 macro- and micro- 
Table 4 Prevalence of inadequacies of usual nutrient intakes among Filipino adults by age and gender groups ${ }^{\mathrm{a}}$

\begin{tabular}{|c|c|c|c|c|c|c|}
\hline \multirow[t]{3}{*}{ Nutrients } & \multicolumn{3}{|c|}{ 19-49 years (young adults) } & \multicolumn{3}{|c|}{50 years and above (older adults) } \\
\hline & \multirow{2}{*}{$\begin{array}{l}\text { Both } \\
\text { genders }\end{array}$} & \multicolumn{2}{|c|}{ Gender } & \multirow{2}{*}{$\begin{array}{l}\text { Both } \\
\text { genders }\end{array}$} & \multicolumn{2}{|c|}{ Gender } \\
\hline & & Male & Female & & Male & Female \\
\hline Sample, $n$ & 12,896 & 6935 & 5961 & 7853 & 3593 & 4314 \\
\hline Total fat (\%) ${ }^{b}$ & $55+$ & $62^{*}$ & 48 & 67 & $72^{*}$ & 63 \\
\hline Protein (\%) ${ }^{b}$ & $2^{\mathrm{NS}}$ & $2^{\text {NS }}$ & 2 & 3 & $3^{\text {NS }}$ & 3 \\
\hline Carbohydrates (\%) ${ }^{\mathrm{b}}$ & $3^{\text {NS }}$ & $3^{\text {NS }}$ & 3 & 2 & $2^{\mathrm{NS}}$ & 1 \\
\hline Protein $(\mathrm{g} / \mathrm{d})$ & $42 \dagger$ & $33^{*}$ & 51 & 62 & $53^{*}$ & 70 \\
\hline Thiamine (mg/d) & $73+$ & $68^{*}$ & 81 & 89 & $86^{*}$ & 92 \\
\hline Riboflavin (mg/d) & $86+$ & $87^{\mathrm{NS}}$ & 86 & 91 & 94 NS & 94 \\
\hline Niacin (mg NE/d) & $10+$ & $5^{*}$ & 13 & 22 & $14^{*}$ & 28 \\
\hline Vitamin A ( $\mu \mathrm{g}$ RE/d) & $54 \dagger$ & $53^{*}$ & 55 & 66 & $65^{*}$ & 67 \\
\hline Vitamin C (mg/d) & $98+$ & $99^{*}$ & 97 & 96 & $97^{*}$ & 95 \\
\hline Vitamin B6 (mg/d) & $28+$ & $17^{*}$ & 38 & 61 & $55^{*}$ & 64 \\
\hline Vitamin B12 $(\mu \mathrm{g} / \mathrm{d})$ & $9+$ & $6^{*}$ & 13 & 17 & $11^{*}$ & 23 \\
\hline Folate ( $\mu \mathrm{g}$ DFE/d) & $90+$ & $86^{*}$ & 93 & 89 & $86^{*}$ & 92 \\
\hline Iron (mg/d) & $97 \dagger$ & $95^{*}$ & 99 & 99 & $95^{*}$ & 97 \\
\hline Calcium (mg/d) & $98+$ & $97^{*}$ & 99 & 95 & $95^{*}$ & 99 \\
\hline Phosphorus (mg/d) & $14 \dagger$ & $6^{*}$ & 24 & 30 & $16^{*}$ & 42 \\
\hline Zinc (mg/d) & $14 t$ & $15^{*}$ & 10 & 34 & $34^{*}$ & 27 \\
\hline Selenium ( $\mu \mathrm{g} / \mathrm{d})$ & $<1^{\mathrm{NS}}$ & $<1^{\text {NS }}$ & $<1$ & 1 & $1^{\mathrm{NS}}$ & 1 \\
\hline
\end{tabular}

Abbreviations: NE Niacin equivalent, RE Retinol equivalent, DFE Dietary folate equivalent

${ }^{\text {a }}$ 8th NNS 2013

Values shown are percentages of study sample below daily Estimated Average Requirement (EAR), with the exception of ${ }^{\mathrm{b}}$ Acceptable Macronutrient Distribution Range (AMDR)

${ }^{\dagger}$ Statistically significant difference between young adults and older adults, $P<0.05$. ${ }^{\text {NS }}$ Not significant

* Statistically significant difference between male and female adults of the same age group, $P<0.05$. ${ }^{\text {NS }}$ Not significant

nutrients among Filipino adults with a nationally representative population sample. Our findings provided important insights on the sub-optimal dietary patterns of Filipino adults, and as a result, the large shortfalls of intakes in many nutrients.

The mean energy intake of both young and older adults was approximately 30\% lower than the recommended intake, which corroborates with the observation, that $10-15 \%$ of them suffer from chronic energy deficiency. In addition, a substantial decline with age in daily energy intakes was observed, which is consistent with many other populations $[27,28]$. The energy needs decrease as people age, possibly attributable to the decrease in muscle mass, physical activity level, and overall basal metabolic rate $[28,29]$. On the other hand, the ageing process could mean reduced ability to absorb and metabolize certain nutrients [30]. It is therefore important for older adults to consume more nutrient-dense foods in order to fulfill their nutritional needs.

The contribution of carbohydrates and protein to energy intake were within the AMDR. However, It is worth noting that the AMDR reference ranges for protein used in Philippines is $10-15 \%$ of total energy intake, which is much narrower towards the lower boundary as compared with $10-35 \%$ used by the Institute of Medicine [17]. In addition, the fact that about half of the Filipino adults' daily protein intake was from grains, mainly refined white rice, suggested a poor quality of dietary protein [31]. The development of EAR for protein in PDRI has taken into consideration the protein quality in Filipino rice-based diet [32], and when compared with the protein EAR, $42-62 \%$ of adults did not meet the recommendation. On the other hand, the low contribution of fats to energy may pose certain problems on the absorption and utilization of fat-soluble vitamins.

A high prevalence of inadequacy was also observed for many vitamins and minerals crucial for adults' optimal health: $50-99 \%$ of adults did not eat adequate vitamin C, calcium, iron, folate, riboflavin, thiamine, vitamin $\mathrm{A}$, and vitamin B6 (only among older adults), while $25-50 \%$ of adults did not meet the EAR for vitamin B6 (young adults), zinc and phosphorus (older adults). In addition, population mean intakes of fiber, vitamin $\mathrm{D}$, vitamin $\mathrm{E}$, magnesium and potassium were far below the adequate intakes. These findings are in general consistent with previous reports in Filipino adults using different dietary intake assessment 
Table 5 Prevalence of inadequacies of usual nutrient intakes among Filipino adults by age and status ${ }^{\mathrm{a}}$

\begin{tabular}{|c|c|c|c|c|c|c|c|c|c|c|}
\hline \multirow[t]{3}{*}{ Nutrients } & \multicolumn{5}{|c|}{ 19-49 years (young adults) } & \multicolumn{5}{|c|}{50 years and above (older adults) } \\
\hline & \multicolumn{5}{|c|}{ Wealth quintiles } & \multicolumn{5}{|c|}{ Wealth quintiles } \\
\hline & Poorest & Poor & Middle & Rich & Richest & Poorest & Poor & Middle & Rich & Richest \\
\hline Sample, $n$ & 2577 & 2653 & 2594 & 2454 & 2308 & 1542 & 1638 & 1552 & 1453 & 1468 \\
\hline Total fat (\%) ${ }^{\mathrm{b}}$ & $90^{*}$ & 77 & 64 & 37 & 17 & $91^{*}$ & 86 & 76 & 55 & 33 \\
\hline Protein (\%) ${ }^{b}$ & $7^{*}$ & 3 & 1 & $<1$ & $<1$ & $9^{*}$ & 4 & 2 & $<1$ & 1 \\
\hline Carbohydrates (\%) ${ }^{\mathrm{b}}$ & $<1^{*}$ & $<1$ & $<1$ & 3 & 9 & $<1^{*}$ & $<1$ & $<1$ & 1 & 3 \\
\hline Protein (g/d) & $57^{*}$ & 50 & 41 & 32 & 30 & $74^{*}$ & 70 & 64 & 57 & 48 \\
\hline Thiamine (mg/d) & $86^{*}$ & 81 & 75 & 66 & 60 & $91^{*}$ & 91 & 89 & 85 & 80 \\
\hline Riboflavin (mg/d) & $94^{*}$ & 92 & 89 & 81 & 76 & $95^{*}$ & 94 & 93 & 91 & 85 \\
\hline Niacin (mg NE/d) & $22^{*}$ & 15 & 8 & 4 & 5 & $36^{*}$ & 29 & 19 & 17 & 12 \\
\hline Vitamin A ( $\mu \mathrm{g} R E / d)$ & $56^{*}$ & 68 & 59 & 50 & 46 & $70^{*}$ & 74 & 72 & 70 & 62 \\
\hline Vitamin C (mg/d) & $96^{*}$ & 98 & 99 & 98 & 98 & $89^{\mathrm{NS}}$ & 91 & 97 & 95 & 89 \\
\hline Vitamin B6 (mg/d) & $40^{*}$ & 38 & 28 & 21 & 14 & $70^{*}$ & 66 & 65 & 61 & 45 \\
\hline Vitamin B12 ( $\mu \mathrm{g} / \mathrm{d})$ & $14^{*}$ & 13 & 10 & 4 & 4 & $27^{*}$ & 22 & 14 & 9 & 8 \\
\hline Folate ( $\mu \mathrm{g}$ DFE/d) & $84^{*}$ & 88 & 93 & 91 & 93 & $83^{*}$ & 88 & 92 & 94 & 91 \\
\hline Iron (mg/d) & $99^{*}$ & 98 & 98 & 96 & 95 & $97^{*}$ & 95 & 95 & 93 & 87 \\
\hline Calcium (mg/d) & $98^{*}$ & 98 & 98 & 98 & 96 & $95^{*}$ & 94 & 95 & 96 & 97 \\
\hline Phosphorus (mg/d) & $23^{*}$ & 17 & 13 & 10 & 11 & $40^{*}$ & 35 & 27 & 28 & 20 \\
\hline Zinc (mg/d) & $29^{*}$ & 21 & 16 & 5 & 4 & $53^{*}$ & 43 & 33 & 25 & 15 \\
\hline Selenium ( $\mu \mathrm{g} / \mathrm{d})$ & $1^{\mathrm{NS}}$ & 1 & $<1$ & 0 & 0 & $4^{*}$ & 2 & 1 & $<1$ & 0 \\
\hline
\end{tabular}

Abbreviations: NE Niacin equivalent, RE Retinol equivalent, DFE Dietary folate equivalent

a 8 th NNS 2013

Values shown are percentages of study sample below daily Estimated Average Requirement (EAR), with the exception of ${ }^{\mathrm{b}}$ Acceptable

Macronutrient Distribution Range (AMDR)

"Statistically significant difference between poorest and richest adults of the same age group, $P<0.05$. NS Not significant

methods [33-35]. Compared to the previous NNS conducted in 2008, there was little improvement in the nutritional inadequacies [35]. Nutrients all play different, yet pivotal roles in the body, and insufficient intakes could increase one's susceptibility to various diseases. The inadequacy of blood-forming nutrients such as folate, vitamin $\mathrm{B} 6$, vitamin $\mathrm{B} 12$, and iron may lead to higher susceptibility to anemia [36-38], increased coronary heart disease risk [39] or poor cognitive outcomes in older adults [40, 41]. Moreover, inadequacy of calcium and vitamin D

Table 6 Population consumption rate and mean consumption per capita of major food groups among Filipino adults ${ }^{a}$

\begin{tabular}{|c|c|c|c|c|c|c|c|}
\hline \multicolumn{4}{|c|}{ 19-49 years (young adults) } & \multicolumn{4}{|c|}{50 years and above (older adults) } \\
\hline Rank & Food groups & $\begin{array}{l}\% \text { of adults } \\
\text { consuming }\end{array}$ & $\begin{array}{l}\text { Mean intake (SE) per } \\
\text { capita }(\mathrm{g})\end{array}$ & Rank & Food groups & $\begin{array}{l}\% \text { of adults } \\
\text { consuming }\end{array}$ & $\begin{array}{l}\text { Mean intake (SE) per } \\
\text { capita (g) }\end{array}$ \\
\hline 1 & Grains & 99.5 & $350.4 \pm 0.6$ & 1 & Grains & 99.6 & $290.8 \pm 0.6$ \\
\hline 2 & Meat \& proteins & 94.8 & $152.3 \pm 0.5$ & 2 & Meat \& proteins & 92.7 & $117.4 \pm 0.5$ \\
\hline 3 & Sweets & 76.9 & $102.3 \pm 0.9$ & 3 & Sweets & 79.2 & $63.4 \pm 0.8$ \\
\hline 4 & Vegetables & 68.5 & $66.4 \pm 0.4$ & 4 & Vegetables & 68.9 & $70.1 \pm 0.5$ \\
\hline 5 & Fats \& oils & 63.1 & $6.2 \pm 0.1$ & 5 & $\begin{array}{l}\text { Other foods \& } \\
\text { beverages }\end{array}$ & 64.6 & $25.7 \pm 1.4$ \\
\hline 6 & $\begin{array}{l}\text { Other foods \& } \\
\text { beverages }\end{array}$ & 62.7 & $35.9 \pm 1.4$ & 6 & Fats \& oils & 57.4 & $5.1 \pm 0.1$ \\
\hline 7 & Fruit & 21.2 & $24.4 \pm 0.8$ & 7 & Fruit & 24.9 & $29.7 \pm 0.9$ \\
\hline 8 & Milk & 9.3 & $2.8 \pm 0.3$ & 8 & Milk & 13.4 & $3.2 \pm 0.2$ \\
\hline 9 & Mixed dishes & 1.9 & $5.1 \pm 1.5$ & 9 & Mixed dishes & 2.1 & $6.0 \pm 1.4$ \\
\hline
\end{tabular}




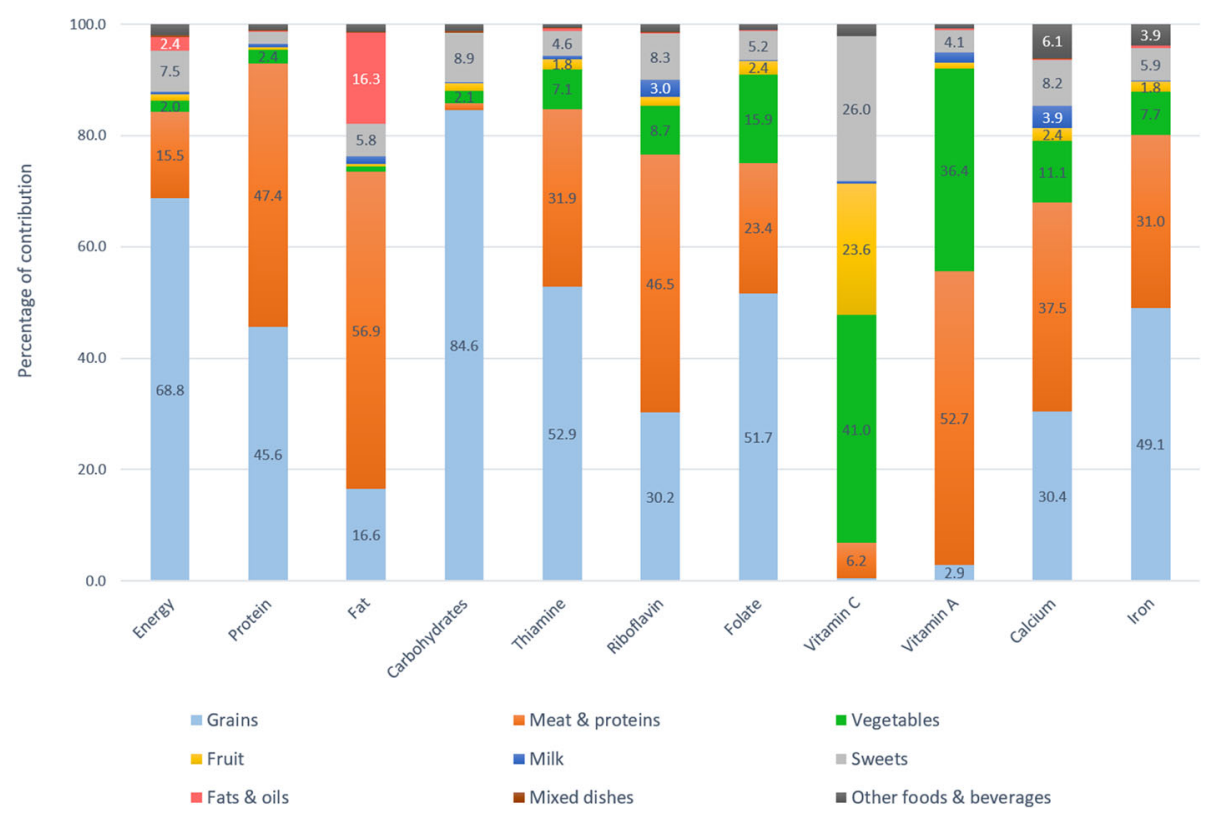

Fig. 1 Food sources of energy and key nutrients among adults aged 19 to 49 years

may increase the risk of osteoporosis and frailty in old age $[42,43]$. Older people may be more vulnerable to calcium and vitamin $\mathrm{D}$ deficiency due to poorer absorption of calcium, reduced vitamin D synthesis in the skin, and decreased ability of the kidney to convert vitamin D to its active form [44]. The markedly high prevalence of calcium inadequacy $(95-98 \%)$ in our study population could be explained by the very low intake of dairy products. Many tropical countries still report a considerable proportion of the population having insufficient vitamin $\mathrm{D}$ levels due to more time spent indoors and less sunlight exposure [45-47]. Food fortification with vitamin $\mathrm{D}$ has been proposed considering that the natural food sources of vitamin D are not commonly consumed in the studied population [43].

The Filipino diet is of limited diversity wherein white rice, pork and breads contributed most to daily intake of energy, protein, carbohydrates, thiamine, riboflavin, and iron. Many nutrient-dense food groups such as

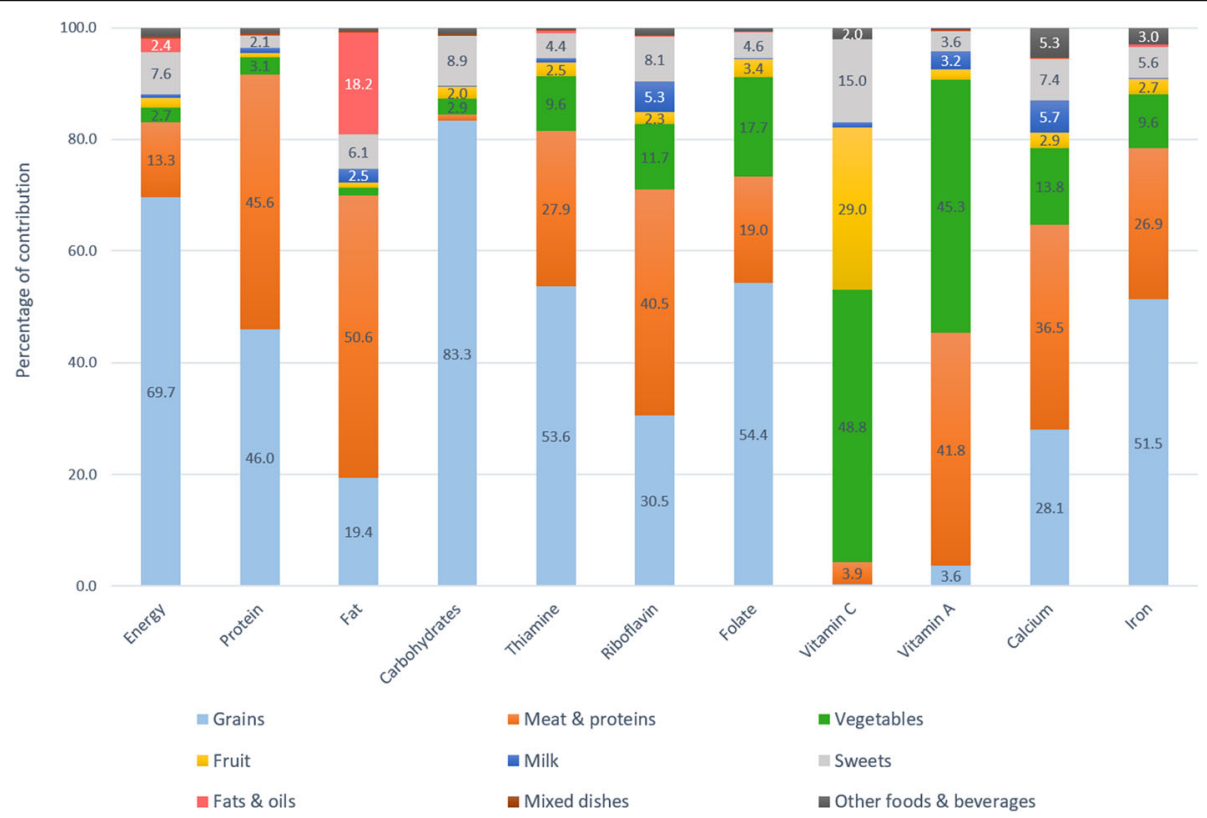

Fig. 2 Food sources of energy and key nutrients among older adults aged 50 years and above 
vegetables, fruit, and dairy were seriously lacking in the diet. Although vegetables and fruits were the top two food sources for vitamin $\mathrm{C}$ and folate, less than $70 \%$ of the population consumed vegetables daily, and even fewer (less than 25\%) consumed fruit, and the amount of consumption was not sufficient to support adults' nutrition needs. Dairy foods, with only $0.4-0.7 \%$ of energy contribution, were the source of $3.9-5.7 \%$ of dietary calcium, $3-5.3 \%$ of riboflavin, and $1.9-3.2 \%$ of vitamin A. Increasing dairy consumption could improve the dietary intake of these key nutrients.

This study also investigated the nutrient intake status across various population subgroups including age, gender, and SES. In general, the prevalence of inadequacy increases with age for most nutrients, in particular thiamine, niacin, vitamin A, vitamin B6, vitamin B12, phosphorus, and zinc. This is due to not only overall reduced food consumption as people age, but also increased nutritional needs because of poorer absorption and metabolism [30]. Also, in both age groups, females are at higher risk of inadequate for thiamine, niacin, vitamin $\mathrm{A}$, vitamin $\mathrm{B} 6$, vitamin $\mathrm{B} 12$, folate, iron, calcium and phosphorus than males, while males are at higher risk for vitamin $\mathrm{C}$ and zinc inadequacy. Although it has been observed in many developed countries that women were more likely to engage in healthy living and healthy dietary choices [48, 49], studies conducted in developing countries as with our study generally reported better nutritional status among the males than females, likely because of the gender differences in social and economic aspects [15]. Lastly, it was observed that the prevalence of inadequate nutrient intake decreases as wealth status progresses, which was also observed in previous studies $[50,51]$. However, increasing SES does not necessarily mean better nutritional status [52]. As demonstrated in the present study, inadequate intake of many key nutrients such as vitamin $C$, iron, calcium, folate and protein remained high even among the richest wealth quintile. Such inadequacies are likely due to the population-wide dietary pattern with low consumption of nutrient-dense foods including fruit, vegetables, and milk. These results demonstrate that overall nutrient intake and dietary diversity need to be improved, with a special focus on interventions for the elderly, females, and those in low SES and food insecure.

This study has provided a comprehensive summary of the dietary intakes and nutritional status of Filipino adults and older adults. The use of mean intakes provided a general overview of nutrient intake levels of the population, while the EAR cut-point method with the national representative sample allowed an estimate of the prevalence of the population with inadequacy intakes. Detailed segmentation of the studied sample by age, gender and SES is instrumental in constructing future tailored nutritional solutions to meet the needs of specific subgroups of the population. However, our study also has several methodological limitations. Firstly, the use of 24-h recalls to collect dietary intake data relies on the participants' ability to accurately recall the foods consumed and estimate the portion sizes of consumption. Secondly, information on use of dietary supplements was not captured in this study, which could under-estimate the nutrient intakes. Thirdly, the construction of the Filipino FCT involved matching similar food items with established databases such as USDA, while in reality, the nutritional content could be different for similar foods, due to different breed cultivars, climate conditions, mineral abundance in soil, and national food fortification policies. Therefore, the findings reported in this study could be subject to measurement errors, and it is warranted to, if possible, relate these dietary intake data with nutritional biomarkers and health conditions to facilitate better interpretation.

\section{Conclusion}

Our findings provided important insights to the dietary patterns of Filipino adults, and showed that marked nutrient inadequacies exist in the adult population, especially among older adults, females, and people from lower SES. The lack of dietary variety and nutritional quality could explain the large shortfalls of many nutrient intakes. A large proportion of energy intake was from foods with low nutrient density such as refined rice and sweets. Nutrient-dense foods such as vegetables, fruits, and dairy products being the least nutrient contributors as shown in the study, should be greatly encouraged to fulfill the nutritional gaps. Food fortification targeting nutrients that are commonly inadequate in the population should also be considered. Together, the findings can help to support the development of specific interventions to improve nutritional status especially among those more vulnerable to dietary inadequacies.

\section{Additional files}

Additional file 1: Dietary reference intakes of nutrients for Filipino adults and older adults. (DOCX $16 \mathrm{~kb}$ )

Additional file 2: Ranking of foods as major sources of energy, protein, total fat, and carbohydrates among adults (19years and above). (DOCX $18 \mathrm{~kb})$

Additional file 3: Ranking of foods as major sources of thiamine, riboflavin, vitamin A, and vitamin C among adults (19years and above). (DOCX 19 kb)

Additional file 4: Ranking of foods as major sources of folate, calcium, and iron among adults (19years and above). (DOCX $16 \mathrm{~kb}$ )

\section{Abbreviations}

AMDR: Average Macronutrient Distribution Range; ANCOVA: Analysis of Covariance; BMI: Body Mass Index; DFE: Dietary Folate Equivalent; EAR: Estimated Average Requirement; EER: Estimated Energy Requirements: FAO: Food and Agriculture Organization; FCT: Food Composition Table; FNRI: Food and Nutrition Research Institute; IDES: Individual Dietary Evaluation Systems; IOM: Institute of Medicine; MUFA: Monounsaturated 
Fatty Acids; NE: Niacin Equivalent; NNS: National Nutrition Survey; PAL: Physical Activity Level; PDRI: Philippine Dietary Reference Intake; PUFA: Polyunsaturated Fatty Acids; RE: Retinol Equivalent; SES: Social Economic Status; USDA: United States Department of Agriculture; WHO: World Health Organization; a-TE: a-tocopherol equivalent

\section{Acknowledgements}

The research described here was a collaboration of 2 organizations: The Department of Science and Technology, Food and Nutrition Research Institute (DOST- FNRI), Philippines (data collection and analyses), and Nestlé Research (Nestec S.A.), Switzerland, (funding source and study conceptualization). The authors would like to acknowledge Kristine T. Biona, Regina R. Rodriguez, Glen Melvin Ginorella and Nabil Bosco, Yvonne Lenighan, and Edelwise Sicat for their support in reviewing the manuscript.

\section{Authors' contributions}

IAA, YS, and LD conceptualized and designed the study, interpreted the data, drafted the initial manuscript, and approved the final manuscript as submitted. AC reviewed and confirmed the appropriateness of the statistical design and interpretations. MVC gave advised and technical inputs. KVT did the statistical data processing and analysis, and RAD. Octavio contributed in drafting the initial manuscript. All authors proof-read and approved the manuscript.

\section{Funding}

The research described here was a collaboration of 2 organizations: The Department of Science and Technology, Food and Nutrition Research Institute (DOST- FNRI), Philippines (data collection and analyses), and Nestlé Research (Nestec S.A.), Switzerland, (funding source and study conceptualization)

\section{Availability of data and materials}

All data generated or analysed during this study are included in this published article and its supplementary information files.

\section{Ethics approval and consent to participate}

The Ethics Committee of FNRI approved the survey protocol. All surveyed households provided informed consent prior to participation.

\section{Consent for publication}

Not applicable.

\section{Competing interests}

The authors declare that they have no competing interests. Y.S and L.D. are employees of Nestec S.A., Switzerland. The opinions expressed in the article are those of the authors alone and do not necessarily reflect the views or recommendations of their affiliations.

\section{Author details}

'Department of Science and Technology, Food and Nutrition Research Institute, Bicutan, Taguig, Philippines. ${ }^{2}$ Nestlé Research, Singapore, Singapore. ${ }^{3}$ Nestlé Research, Lausanne, Switzerland. ${ }^{4}$ lowa State University, Ames, USA.

\section{Received: 6 March 2019 Accepted: 30 August 2019}

Published online: 10 October 2019

\section{References}

1. Global Burden of Disease 2017 Diet Collaborators. Health effects of dietary risks in 195 countries, 1990-2017: a systematic analysis for the global burden of disease study 2017. Lancet. 2019;393(10184):1958-72.

2. Institute for Health Metrics and Evaluation. GBD profile: Philippines. In: Global burden of diseases, injuries, and risk factor s study 2010. Seattle; 2010. https://www.healthypeople.gov/2020/data-source/global-burden-ofdiseases-injuries-and-risk-factors-study. Accessed on 22 Aug 2018.

3. United Nations Department of Economic and Social Affairs Population Division. World population prospects: The 2015 Revision, key findings and advance tables. Working Paper No. ESA/PNWP.241.2015. https:/esa.un.org/unpd/wpp/ publications/files/key_findings_wpp_2015.pdf. Accessed on 5 Dec 2018.

4. Department of Science and Technology- Food and Nutrition Research Institute (DOST-FNRI). The 8th National Nutrition Survey (2013) results - anthropometric survey; Philippines; 2013.
5. Department of Science and Technology- Food and Nutrition Research Institute (DOST-FNRI). The 8th National Nutrition Survey (2013) results - dietary survey: Philippines; 2013.

6. Risonar MG, Rayco-Solon P, Ribaya-Mercado JD, Solon JA, Cabalda AB, Tengco LW, et al. Physical activity, energy requirements, and adequacy of dietary intakes of older persons in a rural Filipino community. Nutr J. 2009. https://doi.org/10.1186/1475-2891-8-19.

7. Department of Science and Technology- Food and Nutrition Research Institute (DOST-FNRI). The 8th National Nutrition Survey (2013) results - biochemical survey; Philippines; 2013.

8. Haddad L, Cameron L, Barnett I. The double burden of malnutrition in SE Asia and the Pacific: priorities, policies and politics. Health Policy Plan. 2015; 30:1193-206.

9. Steyn NP, Michiza ZJ. Obesity and the nutrition transition in sub-Saharan African. N Y Acad Sci, Ann. 2014;1311:88-101.

10. Institute for Health Metrics and Evaluation. Global Burden of Disease (GBD) Country Profiles - Philippines. http:/www.healthdata.org/sites/default/files/ files/country_profiles/GBD/ihme_gbd_country_report_philippines.pdf. Accessed on 22 Aug 2018.

11. Eggersdorfer M, Akobundu U, Bailey RL, Shlisky J, Beaudreault AR, Bergeron $\mathrm{G}$, et al. Hidden hunger: solutions for America's aging populations. Nutrients. 2018. https://doi.org/10.3390/nu10091210.

12. Peter $\mathrm{S}$, Eggersdorfer $M$, van Asselt D, Buskens E, Detzel P, Freijer $K$, et al. Selected nutrients and their implications for health and disease across the lifespan: a roadmap. Nutrients. 2014. https://doi.org/10.3390/nu6126076.

13. Vlassoff C. Gender differences in determinants and consequences of health and illness. J Health Popul Nutr. 2007;25:47-61.

14. World Health Organization. Obesity: preventing and managing the global epidemic. Geneva: WHO press; 1998.

15. Hartman AM, Brown CC, Palmgren J, Pietinen P, Verkasalo M, Myer D, et al. Variability in nutrient and food intakes among older middle-aged men. Implications for design of epidemiologic and validation studies using food recording. Am J Epidemiol. 1990;132:999-1012.

16. Nusser SM, Carriquiry A, Dodd KW, Fuller WA. A semiparametric transformation approach to estimating usual daily intake distributions. J Am Stat Inst. 1991:436:1440-9.

17. Institute of Medicine. Dietary reference intakes for energy, carbohydrate, fiber, fat, fatty acids, cholesterol, protein, and amino acids; the. Washington, DC: National Academies Press; 2005. https://doi.org/10.17226/10490pp.1358.

18. World Health Organization; STEPwise approach to surveillance: 2018. https:// www.who.int/ncds/surveillance/steps/en/. Accessed 25 Jun 2018

19. Lopez-Olmedo N, Carriquiry AL, Rodriguez-Ramirez S, Ramirez-Silva I, Espinosa-Montero J, Hernandez-Barrera L, et al. Usual intake of added sugars and saturated fats is high while dietary fiber is low in the Mexican population. J Nutr. 2016. https://doi.org/10.3945/jn.115.218214.

20. Food and Agriculture Organization of the United Nations. FAO/INFOODS analytical food composition database version 1.1 - AnFooD1.1; 2016.

21. United States Department of Agriculture. What we eat in America food categories. https://www.ars.usda.gov/ARSUserFiles/80400530/pdf/1314/ food_category_list.pdf. Accessed 5 Nov 2018.

22. lowa State University. Software for intake distribution estimation. http:// www.side.stat.iastate.edu/. Accessed 18 Dec 2018.

23. Department of Science and Technology- Food and Nutrition Research Institute (DOST-FNRI). Taguig City: Philippine Dietary Reference Intakes 2015; 2017

24. Beaton GH. Approaches to analysis of dietary data: relationship between planned analyses and choice of methodology. Am J Clin Nutr. 1994;59. https://doi.org/10.1093/ajcn/59.1.253S.

25. National Research Council. Nutrient adequacy: assessment using food consumption surveys. Washington, DC: The National Academies Press; 1986. https://doi.org/10.17226/618pp.160.

26. Department of Science and Technology- Food and Nutrition Research Institute (DOST-FNRI). Taguig City: Nutritional Guildelines for Filipinos revised 2012; 2015.

27. Briefel RR, McDowell MA, Alaimo K, Caughman CR, Bischof AL, Carroll MD, et al. Total energy intake of the US population: the third National Health and nutrition examination survey, 1988-1991. Am J Clin Nutr. 1995;62(5):1072S80S. https://doi.org/10.1093/ajcn/62.5.1072S

28. Wurtman JJ, Lieberman H, Tsay R, Nader T, Chew B. Calorie and nutrient intakes of elderly and young subjects measured under identical conditions. J Gerontol. 1988;43(6):B174-80. 
29. Ahmed T, Haboubi N. Assessment and management of nutrition in older people and its importance to health. Clin Interv Aging. 2010;5:207-16.

30. Amarya S, Singh K, Sabharwal M. Changes during aging and their association with malnutrition. J Clin Gerontol Geriatr. 2015;6:78-84. https:// doi.org/10.1016/j.jcgg.2015.05.003.

31. Rutherfurd SM, Fanning AC, Miller BJ, Moughan PJ. Protein digestibilitycorrected amino acid scores and digestible indispensable amino acid scores differentially describe protein quality in growing male rats. J Nutr. 2015;145: 372-9. https://doi.org/10.3945/jn.114.195438.

32. Barba CV, Cabrera MI. Recommended energy and nutrient intakes for Filipinos 2002. Asia Pac J Clin Nutr. 2008;17(Suppl 2):399-404.

33. Nakatsuka $H$, Zhang ZW, Agetano MG, Subida RD, Inouguchi N, Watanabe $T$, et al. Total food duplicate study on nutrient intake of working women in Manila, the Philippines. Tohoku J Exp Med. 1998; 184:189-205.

34. Gibson RS, Cavalli-Sforza T. Using reference nutrient density goals with food balance sheet data to identify likely micronutrient deficits for fortification planning in countries in the Western Pacific region. Food Nutr Bull. 2012;33:S214-20.

35. Department of Science and Technology-Food and Nutrition Research Institute (FNRI-DOST). The 7th National Nutrition Survey (2008) results - food consumption survey; Philippines; 2008.

36. Beard JL, Connor JR. Iron status and neural functioning. Annu Rev Nutr. 2003;23:41-58. https://doi.org/10.1146/annurev.nutr.23.020102.075739.

37. Failla ML. Trace elements and host defense: recent advances and continuing challenges. J Nutr. 2003;133:1443s-7s. https://doi.org/10. 1093/jn/133.5.1443S

38. Haas JD, Brownlie IVT. Iron deficiency and reduced work capacity: a critical review of the research to determine a causal relationship. J Nutr. 2001;131: 676S-90S. https://doi.org/10.1093/jn/131.2.676S.

39. Thomas DR. Vitamins in aging, health, and longevity. Clin Interv Aging. 2006;1:81-91.

40. ter Borg S, Verlaan S, Hemsworth J, Mijnarends DM, Schols JM, Luiking YC, et al. Micronutrient intakes and potential inadequacies of community-dwelling older adults: a systematic review. Br J Nutr. 2015;113:1195-206. https://doi.org/10. 1017/s0007114515000203.

41. Doets EL, Ueland PM, Tell GS, Vollset SE, Nygard OK, Van't Veer P, et al. Interactions between plasma concentrations of folate and markers of vitamin B(12) status with cognitive performance in elderly people not exposed to folic acid fortification: the Hordaland health study. $\mathrm{Br}$ J Nutr. 2014;111:1085-95. https://doi.org/10.1017/s000711451300336x.

42. Heaney RP. Calcium, dairy products and osteoporosis. J Am Coll Nutr. 2000; 19:83s-99s.

43. Halfon M, Phan O, Teta D. Vitamin D: a review on its effects on muscle strength, the risk of fall, and frailty. Biomed Res Int. 2015:953241-1. https:// doi.org/10.1155/2015/953241.

44. Veldurthy V, Wei R, Oz L, Dhawan P, Jeon YH, Christakos S. Vitamin D, calcium homeostasis and aging. Bone Res. 2016:4:16041. https://doi.org/10. 1038/boneres.2016.41.

45. Robien K, Butler LM, Wang R, Beckman KB, Walek D, Koh WP, et al. Genetic and environmental predictors of serum 25 -hydroxyvitamin $\mathrm{D}$ concentrations among middle-aged and elderly Chinese in Singapore. Br J Nutr. 2013;109: 493-502. https://doi.org/10.1017/S0007114512001675.

46. Chin KY, Ima-Nirwana S, Ibrahim S, Mohamed IN, Wan Ngah WZ. Vitamin D status in Malaysian men and its associated factors. Nutrients. 2014;6:5419-33. https://doi.org/10.3390/nu6125419.

47. Bi X, Tey SL, Leong C, Quek R, Henry CJ. Prevalence of vitamin D deficiency in Singapore: its implications to cardiovascular risk factors. PLoS One. 2016; 11:e0147616. https://doi.org/10.1371/journal.pone.0147616.

48. Ek S. Gender differences in health information behaviour: a Finnish population-based survey. Health Promot Int. 2015;30:736-45. https://doi.org/ 10.1093/heapro/dat063.

49. Vitale M, Masulli M, Cocozza S, Anichini R, Babini AC, Boemi M, et al. Sex differences in food choices, adherence to dietary recommendations and plasma lipid profile in type 2 diabetes - the TOSCA.IT study. Nutr Metab Cardiovasc Dis. 2016;26:879-85. https:// doi.org/10.1016/j.numecd.2016.04.006.

50. Cruz-Gongora V, Martinez-Tapia B, Cuevas-Nasu L, Flores-Aldana M, ShamahLevy T. Dietary intake and adequacy of energy and nutrients in Mexican older adults: results from two National Health and nutrition surveys. Salud Publica Mex. 2017;59:285-98. https://doi.org/10.21149/7851.
51. Nguyen PH, Nguyen H, Gonzalez-Casanova I, Copeland E, Strizich G, Lowe A, et al. Micronutrient intakes among women of reproductive age in Vietnam. PLoS One. 2014;9:e89504. https://doi.org/10.1371/journal.pone.0089504.

52. Nikolic M, Glibetic M, Gurinovic M, Milesevic J, Khokhar S, Chillo S, et al. Identifying critical nutrient intake in groups at risk of poverty in Europe: the CHANCE project approach. Nutrients. 2014;6:1374-93. https://doi.org/10.3390/nu6041374.

\section{Publisher's Note}

Springer Nature remains neutral with regard to jurisdictional claims in published maps and institutional affiliations.
Ready to submit your research? Choose BMC and benefit from:

- fast, convenient online submission

- thorough peer review by experienced researchers in your field

- rapid publication on acceptance

- support for research data, including large and complex data types

- gold Open Access which fosters wider collaboration and increased citations

- maximum visibility for your research: over $100 \mathrm{M}$ website views per year

At BMC, research is always in progress.

Learn more biomedcentral.com/submissions 